\title{
ASSESSMENT OF MICROBIOLOGICAL AEROSOL CONCENTRATION IN SELECTED HEALTHCARE FACILITIES IN SOUTHERN POLAND
}

\author{
Joanna Stec ${ }^{1}$, Anna Lenart-Boroń ${ }^{2}$ \\ ${ }^{1}$ Faculty of Biotechnology and Horticulture, University of Agriculture in Krakow, Krakow, Poland \\ ${ }^{2}$ Department of Microbiology, Faculty of Agriculture and Economics, University of Agriculture in Krakow, Krakow, Poland
}

\section{SUMMARY}

Objectives: This study was aimed to assess the concentration of microbial aerosol and species composition of airborne staphylococci in 10 healthcare facilities in southern Poland including primary healthcare units and hospital wards; and to assess whether the selected components of microbial aerosol pose a threat of severe infections to either patients or the personnel.

Methods: The study was conducted at monthly intervals over a period of one year. Air samples were collected by MAS- 100 sampler. The number of mesophilic bacteria, mould fungi, actinomycetes and staphylococci was determined on general and selective media. The species identification of staphylococci was conducted using API tests for strains that were pre-selected based on macroscopic and microscopic observations.

Results: A total number of 1,584 samples were collected during the sampling period. The numbers of airborne microorganisms varied between the examined premises and between the seasons of the year. The observed differences were statistically significant with one exception for actinomycetes and their differences between the examined premises. The concentrations of mesophilic bacteria varied from 5 to $297 \mathrm{CFU} / \mathrm{m}^{3}$ of air, for Staphylococcus the values ranged from 1 to $96 \mathrm{CFU} / \mathrm{m}^{3}$, for fungi - from 1 to $100 \mathrm{CFU} / \mathrm{m}^{3}$, and the number of actinomycetes ranged from 7 to $321 \mathrm{CFU} / \mathrm{m}^{3}$. Ten species of coagulase-negative staphylococci (CoNS) were identified among 55 isolates with S. saprophyticus and S. warneri being the most frequently detected ( $n=14$ and 13 , respectively). S. haemolyticus, which is one of the most common causal agents of nosocomial infections was observed in four facilities $(n=5)$.

Conclusions: The microbial concentrations varied both between the seasons of the year and between the examined facilities. The highest bioaerosol concentrations were observed in most crowded premises. The identified species of staphylococci, although not typically associated with human infections, are common causal agents of nosocomial infections and infections in immunocompromised people.

Key words: airborne microorganisms, healthcare facilities, bioaerosol, microbial aerosol, Staphylococcus spp.

Address for correspondence: A. Lenart-Boron, Department of Microbiology, Faculty of Agriculture and Economics, University of Agriculture in Kraków, 24/28 Mickiewicza Ave., 30-059 Kraków, Poland. E-mail: a.lenart-boron@ur.krakow.pl

https://doi.org/10.21101/cejph.a5681

\section{INTRODUCTION}

The concentration of airborne microorganisms in healthcare facilities can be affected by a number of different biotic and abiotic factors. Biotic, or biological factors include the health condition of both personnel and patients, as well as the presence of persons who can be transmitters of microorganisms (1). Another problem related to microbial contamination of air in healthcare units is related to the appearance of microorganisms of modified properties, mainly antibiotic resistant bacteria (2).

By using precise measuring techniques and by culturing the air samples on blood agar for $24-48 \mathrm{~h}$ at $35^{\circ} \mathrm{C}$, Bischoff et al. (3) demonstrated that sneezing causes a highly significant increase in S. aureus, coagulase-negative staphylococci (CoNS) and other (not determined to the species level) bacteria in environmental samples. One sneeze expels, on average, mostly other bacteria, such as $\alpha$-haemolytic streptococci ( $474 \mathrm{CFU} / \mathrm{m}^{3} / \mathrm{min}$ ), but also 3.24 $\mathrm{CFU}$ of CoNS $/ \mathrm{m}^{3} / \mathrm{min}$ and $2.83 \mathrm{CFU}$ of $S$. aureus $/ \mathrm{m}^{3} / \mathrm{min}$. Also, mean airborne counts may reach up to 15,47 and 2,522 CFU/m $3 /$ $\min$ for $S$. aureus, CoNS and other bacteria after sneezing. During sneezing, the infected person emits up to 40,000 droplets with the velocity of $100 \mathrm{~m} / \mathrm{s}$. Larger droplets fall to the ground very quickly, but the smaller ones evaporate and become droplet nuclei, which are typically $1-5 \mu \mathrm{m}$ in diameter and can remain suspended in the air for long hours (4). Such small numbers of droplet nuclei allow them to pass the host defence mechanisms and the human upper respiratory tract to be deposited in the alveoli in the lungs (4). Additionally, spreading of bioaerosol is affected by the air movement caused by ventilation, differences in temperature or humidity, or even moving of hospital equipment (5). Another group of abiotic factors affecting transmission of microorganisms includes the types of carriers, such as the materials of which the equipment is made, clothes or room facilities, and equipment (1). Studies show that in hospital conditions microorganisms can be deposited on clothing of medical personnel, blankets or towels and that the survival rate depends on the microbial genus or species. For instance, the highest survival rate on towels and cotton clothes was detected for Staphylococcus spp., enterococci and mould fungi $(1,6)$. 
While healthcare facilities face challenges common to all buildings, they meet an additional challenge of high-density populations of potentially contagious and immunocompromised people (7). This results in various problems regarding infection control, since all respiratory pathogens may cause hospital-acquired infections (8). The list of known hospital-acquired infections presented by, among others, Fernstrom and Goldblatt, (7) includes those caused by different viruses, as well as fungi such as Aspergillus spp., Mucor or Rhizopus stolonifer, or bacteria such as Mycobacterium, Nocardia, Pseudomonas aeruginosa or staphylococci.

Having in mind the significance of the problem related to the microbiological quality of air in a specific group of places such as hospitals and healthcare facilities, the study was undertaken in order to assess the concentration as well as the composition of microbial aerosol in the selected healthcare facilities (outpatient units and hospital wards) in southern Poland. Particular attention was paid to the concentration and species composition of Staphylococcus spp., as some species of these bacteria, such as S. aureus, S. epidermidis, S. saprophyticus or S. haemolyticus may be associated with particularly severe infections acquired in hospitals and healthcare units $(2,9)$.

\section{MATERIALS AND METHODS}

The study was conducted over a period of one year, at monthly intervals from May 2014 to April 2015 in ten selected healthcare facilities (Table 1), including four waiting rooms of outpatient specialized units (I-IV), one hospital waiting room (V), one treatment room of an infectious ward (VI), two sickrooms - one of a children's ward (VII) and of an intensive care unit (VIII), intensive care room of a cardiology ward (IX), and isolation ward of an intensive care unit (X). Atmospheric air collected in the park outside one of the units was treated as control (C). Air samples of $100 \mathrm{~L}$ were taken using MAS-100 (Merck) air sampler (with the cut-off size of $1.47 \mu \mathrm{m}$ ). The measurements were conducted according to the procedure described in the PN-Z-04008-08:1989 standard (10), which means that the sampler was placed at approximately $1.5 \mathrm{~m}$ above the ground, i.e. in the human breathing zone and the volume of air collected was empirically adjusted to the expected concentration of microbiological aerosol. The measurements were conducted on usual working days of the tested facilities, when both the patients and the personnel were present. The approximate hours of sampling were from 10 to 13 (i.e. during the visiting hours in hospitals and during regular working hours of outpatient units). The numbers of the total mesophilic bacteria (Trypticase Soy Agar - Biocorp, $48 \mathrm{~h}$ at $36 \pm 1^{\circ} \mathrm{C}$ ), fungi (Malt Extract Agar-Biocorp, 3-5 days at $24^{\circ} \mathrm{C}$ ), actinomycetes (Gauze Medium, 7 days at $24^{\circ} \mathrm{C}$ ) and staphylococci (Chapman Agar Biocorp, $48 \mathrm{~h}$ at $36 \pm 1^{\circ} \mathrm{C}$ ) were assessed. After incubation, the numbers of colonies characteristic for different microbial groups were counted and expressed as colony forming units per cubic meter of air $\left(\mathrm{CFU} / \mathrm{m}^{3}\right)$. The actual colony count per each culture plate was corrected according to the positive hole correction table (Operator's manual MAS-100) (11). All measurements were conducted in triplicates, which - having regard to the fact that the sample collection was conducted in eleven sites, once per month over a year, with four groups of microorganisms - gives a total number of 1,584 samples collected during the sampling period. The results from three replications were used to calculate mean values, which are shown as final results in Figures. The samples were collected one after another and between each sampling, the impactor was disinfected by using cotton balls immersed in $70 \%$ ethanol. Currently, there are no generally applicable standards that would determine the limit values for concentrations of airborne microorganisms. Therefore, the results obtained based on the analysis were compared to the proposed guidelines by the Team of Experts in Biological Factors (Polish acronym ZECB) (12) on the concentrations of airborne microorganisms in indoor air, including living spaces and public utility premises.

Moreover, after incubation, characteristic colonies grown on Chapman medium were selected for further analysis. Pure cultures were obtained by plate streaking on Chapman medium. Further identification was based on Gram staining, furazolidone sensitivity test and API Staph tests (BioMerieux).

Statistical analysis was performed using Statistica v.10 (StatSoft) - basic descriptive statistics were calculated, and a one-way ANOVA test was employed to verify the significance of seasonal differences in the number of microorganisms and the differences between individual healthcare facilities.

Table 1. Sampling sites

\begin{tabular}{|l|c|c|c|}
\hline Sampling sites & Symbol & $\begin{array}{c}\text { Approximate number } \\
\text { of persons per day }\end{array}$ & Indoor temperature ( $\left.{ }^{\circ} \mathrm{C}\right)$ \\
\hline Internal medicine outpatient clinic 1 - waiting room & $\mathrm{I}$ & 350 & $23.2(20.6-29.7)$ \\
\hline Specialist outpatient clinic - waiting room & II & 250 & $22.7(19.3-26.3)$ \\
\hline Allergology outpatient clinic - waiting room & III & 200 & $22.2(20.1-25.9)$ \\
\hline Internal medicine outpatient clinic 2 - waiting room & IV & 250 & $24.6(21.6-29.5)$ \\
\hline Hospital 1 - waiting room & V & 300 & $24.4(22.7-27.2)$ \\
\hline Hospital 2 infectious ward - treatment room & VI & 40 & $24.6(23.3-26.9)$ \\
\hline Hospital 3 children's ward - sickroom & VII & 20 & $26.8(22.4-32.5)$ \\
\hline Hospital 4 intensive care unit - sickroom & VIII & 6 & $23.1(21.8-27.6)$ \\
\hline Hospital 5 cardiology ward - intensive care room & IX & 4 & $22.7(21.1-23.7)$ \\
\hline Hospital 4 intensive care unit - isolation ward & X & C & $22.2(19.6-24.4)$ \\
\hline Control site - outdoor air, park in front of one of the units & C applicable & $10.2(-7.5-26.9)$ \\
\hline
\end{tabular}




\section{RESULTS}

The results of the conducted studies are summarized in Figures $1-5$. The values presented in Figures 1-4 are means of measurements conducted in triplicates in individual months. The results presented in Fig. 5 are means of measurements conducted annually.

The analysis of variance showed that the differences between the studied locations in the numbers of mesophilic bacteria, staphylococci and fungi were statistically significant ( $\mathrm{F}$ value of $7.67,2.67$ and 3.24, respectively, $p<0.05$ ). Only in the case of actinomycetes these differences appeared not to be significant. Also, the analysis of the differences in the microbial numbers between the seasons of the year indicated the statistical significance of differences ( $F$ value of 3.18, 3.86, 20.94 and 9.28 for mesophilic bacteria, staphylococci, fungi and actinomycetes, respectively). The differences are significant at $\mathrm{p}<0.05$.

The number of mesophilic bacteria ranged from $5 \mathrm{CFU} / \mathrm{m}^{3}$ (site No. IV, winter) to $297 \mathrm{CFU} / \mathrm{m}^{3}$ (No. V, autumn). Also, as shown in Fig. 1, the greatest concentration of mesophilic bacteria was observed in autumn and winter - in autumn the highest values were recorded in the sites No. II, III, IV and V, while in winter
- in the sites No. VI, VII and IX. The smallest mean number of these microorganisms was observed in the facility No. VIII, i.e. $23 \mathrm{CFU} / \mathrm{m}^{3}$ while the greatest mean number, $128 \mathrm{CFU} / \mathrm{m}^{3}$, in the facility No. V (Fig. 5).

The number of airborne staphylococci varied between $1 \mathrm{CFU} /$ $\mathrm{m}^{3}$ (IX, spring) to $96 \mathrm{CFU} / \mathrm{m}^{3}$ (IX, winter). In most of the studied sites the greatest values of staphylococcal concentration were recorded in summer - sites No. I, III, IV, V, VIII and X (Fig. 2). The mean numbers of staphylococci ranged from $8 \mathrm{CFU} / \mathrm{m}^{3}$ in the site No. IV and $9 \mathrm{CFU} / \mathrm{m}^{3}$ in the site No. $\mathrm{X}$ to $38 \mathrm{CFU} / \mathrm{m}^{3}$ in the site No. IX (Fig. 5).

As shown in Fig. 3, the highest values of fungi were also detected in summer in all of the examined sites and they ranged from $1 \mathrm{CFU} / \mathrm{m}^{3}$ in winter at the site No. VIII to $100 \mathrm{CFU} / \mathrm{m}^{3}$ in summer at the site No. IV. In general, the smallest number of fungi was recorded at the facility No. VIII $\left(6 \mathrm{CFU} / \mathrm{m}^{3}\right)$ while the largest value was observed at the facility No. II (i.e. $43 \mathrm{CFU} / \mathrm{m}^{3}$ ) (Fig. 5).

Finally, the greatest numbers of actinomycetes were observed in winter - in six out of ten studied healthcare facilities, i.e. No. I, II, III, IV, VIII and IX. The concentration of airborne actinomycetes ranged from $7 \mathrm{CFU} / \mathrm{m}^{3}$ (site No. IV both in spring and autumn) to $231 \mathrm{CFU} / \mathrm{m}^{3}$ (site No. VII in winter) (Fig. 4). As

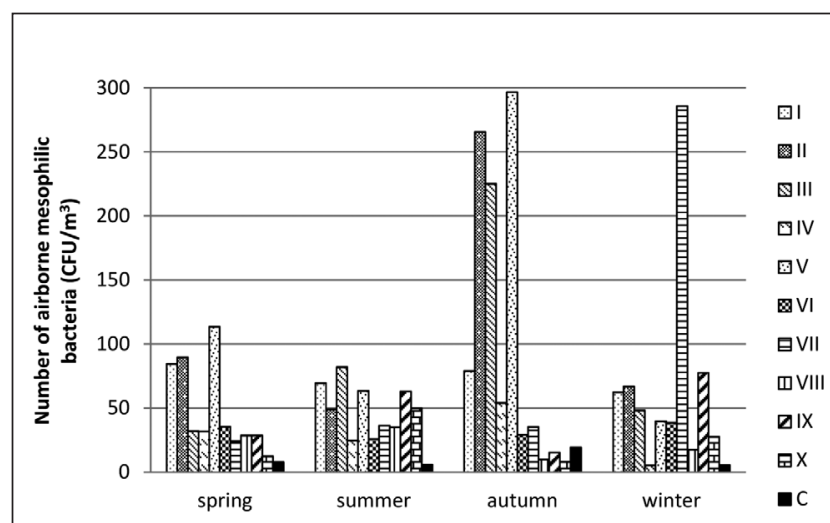

Fig. 1. Mean numbers of mesophilic bacteria in studied locations and seasons $\left(\mathrm{CFU} / \mathrm{m}^{3}\right)$.

I-X - numbers of tested facilities; C - control site located outdoors

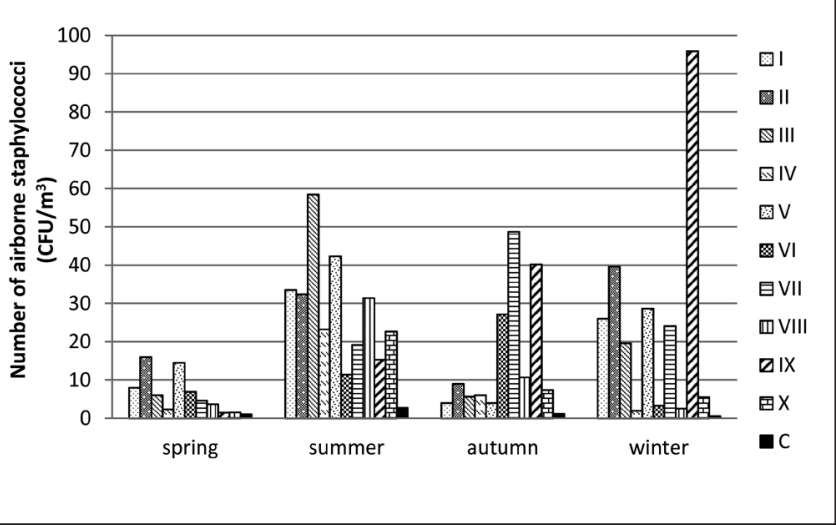

Fig. 2. Mean numbers of staphylococci in studied locations and seasons $\left(\mathrm{CFU} / \mathrm{m}^{3}\right)$.

I-X - numbers of tested facilities; C - control site located outdoors

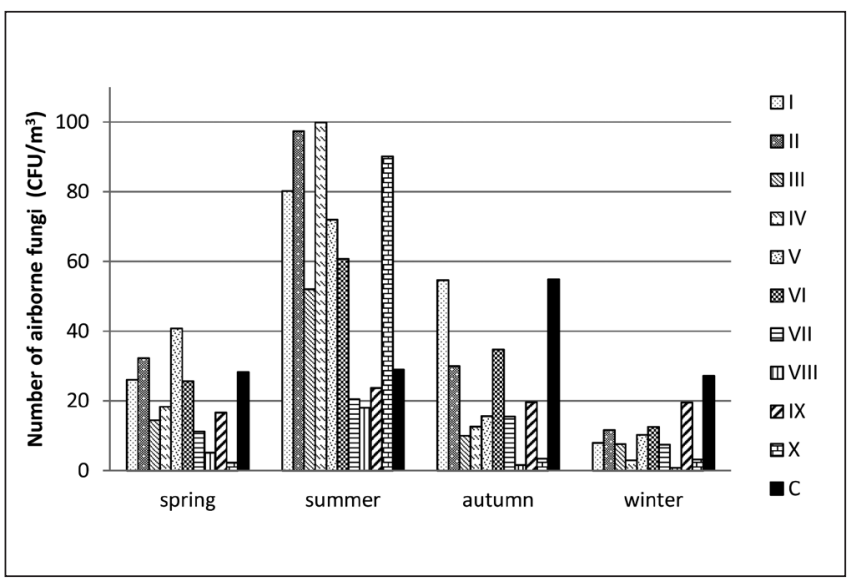

Fig. 3. Mean numbers of fungi in studied locations and seasons $\left(\mathrm{CFU} / \mathrm{m}^{3}\right)$.

I-X - numbers of tested facilities; $\mathrm{C}$ - control site located outdoors

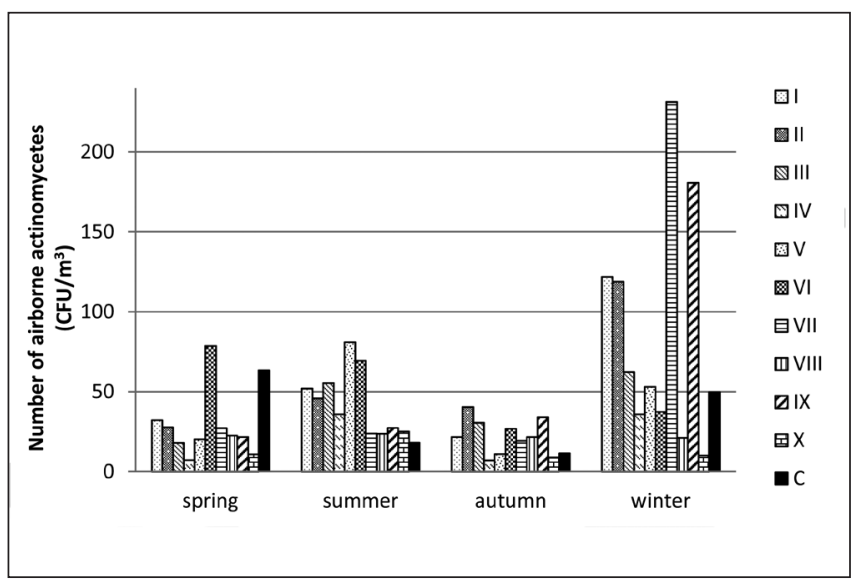

Fig. 4. Mean numbers of actinomycetes in studied locations and seasons $\left(\mathrm{CFU} / \mathrm{m}^{3}\right)$.

I-X - numbers of tested facilities; $\mathrm{C}$ - control site located outdoors 


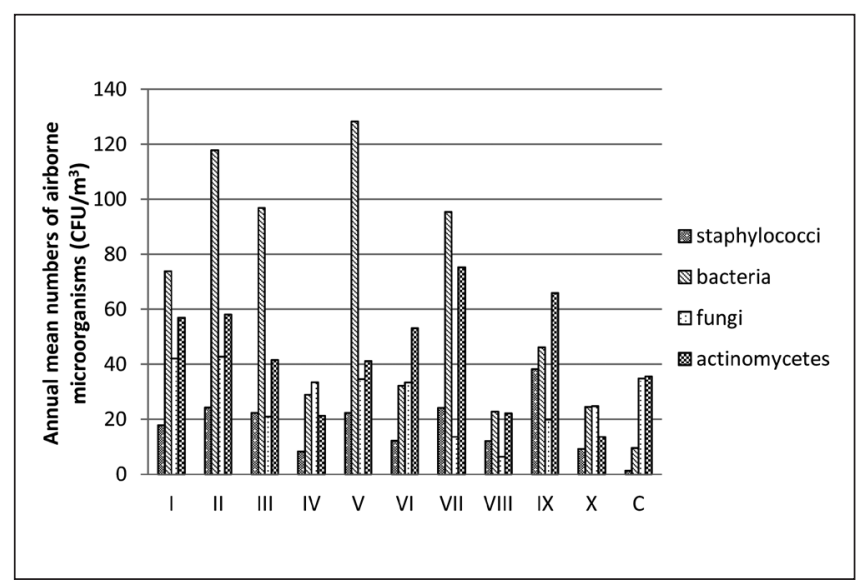

Fig. 5. Annual mean numbers of airborne microorganisms in studied healthcare facilities $\left(\mathrm{CFU} / \mathrm{m}^{3}\right)$.

I-X - numbers of tested facilities; $\mathrm{C}$ - control site located outdoors

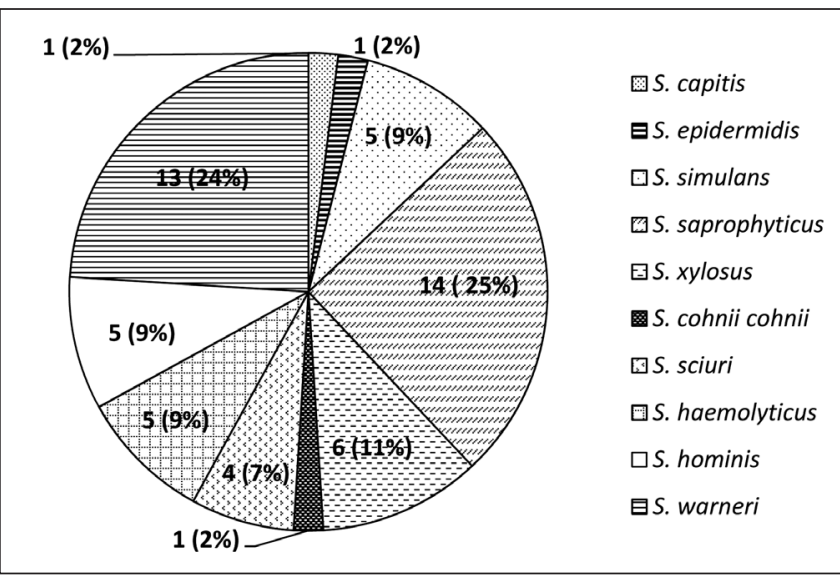

Fig. 6. Numbers and share (\%) of individual staphylococci species in the total of 55 isolates.

indicated in Fig. 5., also the mean number of actinomycetes was the largest at the facility No. VII (i.e. $75 \mathrm{CFU} / \mathrm{m}^{3}$ ), while the minimum number was recorded at the site No. X $-14 \mathrm{CFU} / \mathrm{m}^{3}$.

After analysis of the microbial aerosol concentration, the selected isolates of Staphylococcus spp. were purified and a total of 55 strains were obtained and identified, a share of the species is shown in Fig. 6. S. saprophyticus and S. warneri were the predominant species, as they constituted as much as 25 and $24 \%$ of the total Staphylococcus spp. isolates, respectively.

\section{DISCUSSION}

The problem of microbiological contamination of air is associated with many different types of premises, including university rooms, offices, laboratories, canteens as well as healthcare centres and hospitals (13-17). This problem becomes even more severe when it can affect the health of people dwelling in such premises, as in the case of healthcare units and hospitals. The respiratory system of human organism is a gateway for bacterial or viral infections, as well as for environmental pollutants. After colonization of mucous membranes, microorganisms can dwell asymptomatically and in cases of impaired host resistance
- they can cause respiratory infections and in severe cases such infection can spread throughout the body. The most important step in bacterial colonization is their adhesion to epithelial cells, where they must survive the purification by secreted mucus. Both pathogens, such as Streptococcus pneumoniae or Haemophilus influenzae and widespread coagulase-negative staphylococci (CoNS) form biofilms during the respiratory tract infections. This may contribute to, among others, ventilator-associated pneumonia (18). Nosocomial infections can also be caused by the presence of high concentrations of fungi, including the most commonly found environmental moulds, such as Aspergillus, Mucorales, Paecilomyces, Cladosporium, Fusarium and others (19).

There are no regulations concerning the acceptable levels of microbial aerosol concentration in indoor air in Poland (2). According to the "Design guidelines for general hospitals" there are three classes of hospital premises, depending on their cleanliness (20):

Class I - premises of the highest possible aseptic - the minimum level of bacteria, including sterile boxes, highly aseptic operating rooms etc., with the permissible concentration of 70 CFU of bacteria $/ \mathrm{m}^{3}$ of air.

Class II - premises with low levels of bacteria, including septic and aseptic operating rooms, post-operating rooms and intensive care units with bed premises, with the permissible concentration of $300 \mathrm{CFU}$ of bacteria $/ \mathrm{m}^{3}$ of air.

Class III - premises with normal levels of bacteria, including treatment rooms or diagnostic premises, with the maximum permissible concentration of $700 \mathrm{CFU}$ of bacteria $/ \mathrm{m}^{3}$ of air.

Two of the premises examined in this study can be included into class II (sites No. IX and X), while the remaining premises belong to class III. Thus, considering the number of mesophilic bacteria, the permissible level was not exceeded in any of the examined cases.

The microbial aerosol concentrations recorded in our study were also compared to the guideline proposals, given by the Polish Team of Experts in Biological Factors (12) on the concentrations of airborne microorganisms in indoor air, including living spaces and public utility premises. Among the microorganisms examined in our study, this proposal includes mesophilic bacteria and fungi, and the concentrations observed in our study did not exceed the proposed limits, which were $5 \times 10^{3} \mathrm{CFU} / \mathrm{m}^{3}$ for mesophilic bacteria and $5 \times 10^{3} \mathrm{CFU} / \mathrm{m}^{3}$ for fungi, as the maximum numbers of mesophilic bacteria was $297 \mathrm{CFU} / \mathrm{m}^{3}$ and for fungi $+100 \mathrm{CFU} / \mathrm{m}^{3}$.

The recorded concentrations of mesophilic bacteria are in between the ones observed by other authors, as e.g. even the highest concentration observed in this study, i.e. $297 \mathrm{CFU} / \mathrm{m}^{3}$ was lower than the smallest values in the study by Karwowska et al. (2), who observed the number of mesophilic bacteria ranging from $320-560 \mathrm{CFU} / \mathrm{m}^{3}$ in the patients' waiting rooms. On the other hand, the concentration of bioaerosol composed of mesophilic bacteria in the children hospital sickrooms (site No. VII - values ranging from 24 to even $286 \mathrm{CFU} / \mathrm{m}^{3}$ in winter) were higher than the ones observed by $\mathrm{Li}$ and Hou (21), where they were lower than $160 \mathrm{CFU} / \mathrm{m}^{3}$. In 2005, Pastuszka et al. (22) published their preliminary results of measurements conducted in Silesian hospitals, in which the level of bacterial aerosol was found to be about $10^{3} \mathrm{CFU} / \mathrm{m}^{3}$ in clinical outpatient rooms and ranged from $10^{2} \mathrm{CFU} / \mathrm{m}^{3}$ to $10^{3} \mathrm{CFU} / \mathrm{m}^{3}$ in hospitals, depending on the number of occupants and physical quality of the building. In our study, the level of $10^{2} \mathrm{CFU} / \mathrm{m}^{3}$ of bacteria was exceeded 
only five times, mostly in waiting rooms, where the number of persons per day exceeded 200. The only patient room, where the level of bacterial aerosol was the highest, was in the children's hospital in winter. Generally, in winter the numbers of microbial components of bioaerosol were very high in the children's hospital and the highest numbers of actinomycetes were observed in these particular premises. This can be related to the fact that winter is the period of increased infections, which also affected the number of patients in this hospital. Moreover, rooms in this hospital are small with carefully closed doors and windows, and with each child patient being accompanied by at least one parent, the rooms became severely overcrowded.

The maximum concentration of Staphylococcus spp., i.e. $96 \mathrm{CFU} / \mathrm{m}^{3}$ as well as the highest mean concentration of these bacteria was recorded at the site No. IX, which is the intensive care unit of the cardiology ward. The observed concentrations of staphylococci are slightly higher than the ones observed by Klánová and Hollerová (23), who recorded the values ranging from 5 to $70 \mathrm{CFU} / \mathrm{m}^{3}$. On the other hand, our values are much lower than the ones recorded by Karwowska et al. (2), who observed the concentrations of staphylococci even up to $350 \mathrm{CFU} /$ $\mathrm{m}^{3}$. However, patients of this ward are very often intubated people, whose breathing is supported with ventilators, in which even small concentrations of staphylococci may promote the emergence of nosocomial infections (24). Also, in the study by Pastuszka et al. (22), the numbers of staphylococci were mostly higher than the ones observed in our study, as they ranged from $60 \mathrm{CFU} / \mathrm{m}^{3}$ in an operating room to $379 \mathrm{CFU} / \mathrm{m}^{3}$ in one of the patient rooms. The values recorded in this study did not exceed the level of $60 \mathrm{CFU} /$ $\mathrm{m}^{3}$, except for one observation, mentioned earlier, i.e. $96 \mathrm{CFU} / \mathrm{m}^{3}$ in the intensive care unit of the cardiology ward. It needs to be mentioned, that the study by Pastuszka et al. (22) was conducted nearly 15 years ago, therefore, the observed differences may result from the fact that the procedures used in outpatient clinics and hospitals have changed over this period, and it may provide an interesting suggestion to conduct a detailed analysis of the changes in the bioaerosol levels in hospital premises, as a possible result of the renovations and procedure changes.

As for the number of fungi, the concentrations detected in this study, ranging from 1 to $100 \mathrm{CFU} / \mathrm{m}^{3}$, are higher than the ones reported by Karwowska et al. (2), who observed the values of $15-35 \mathrm{CFU} / \mathrm{m}^{3}$ of air. They are very similar to the values observed by Augustowska and Dutkiewicz (25), which range from 10 to 96 $\mathrm{CFU} / \mathrm{m}^{3}$ and they are smaller than those observed by $\mathrm{Li}$ and Hou (21), i.e. $260 \mathrm{CFU} / \mathrm{m}^{3}$. Still, the observed values do not exceed the limits proposed by the Team of Experts (12), i.e. $500 \mathrm{CFU} / \mathrm{m}^{3}$ of air for indoor air and public utility premises or by Krzysztofik (26), set at $200 \mathrm{CFU} / \mathrm{m}^{3}$ of air for sickrooms.

The values of airborne actinomycetes ranged from $7 \mathrm{CFU} / \mathrm{m}^{3}$ in one of the sickrooms to $231 \mathrm{CFU} / \mathrm{m}^{3}$ in the children's ward. The highest concentration was recorded in winter, similarly to the number of mesophilic bacteria - in the period when the rooms were overcrowded with patients and their parents. In addition to the fact that actinomycetes are well recognized indoor air pollutants, high concentrations of their spores in the air are related to the incidence of allergic alveolitis and asthma, as well as other health effects (27). According to Hirvonen et al. (28), the spores of Streptomyces spp. can stimulate lung macrophage reactions, resulting in inflammation and tissue injury.
A total of 55 isolates belonging to the genus Staphylococcus were subjected to further identification, which revealed the presence of 10 different species, all of which were coagulase negative (CoNS). Among them, S. saprophyticus $(\mathrm{n}=14)$ and $S$. warneri $(n=13)$ were most frequently detected. Until recently, CoNS were described as ubiquitous commensals of healthy human skin and mucosa. However, they are being more frequently reported as important opportunistic pathogens, mainly associated with healthcare-acquired infections in patients with indwelling medical devices (29). The most abundant in this study, S. saprophyticus, which is a part of a human microflora, is also one of the most frequent agents of community-acquired urinary tract infections $(30,31)$. The second most frequently identified species, $S$. warneri was isolated from one of the healthcare units and four hospital wards, including cardiology, sickroom of an intensive care unit and an infectious ward, whose patients' immune system may be compromised. This information might be important, as this species was reported to cause infections in hospitalized patients and was also suggested as a cause of, among others, ventricular shunt infections, endocarditis and even sepsis $(32,33)$. One of the most dangerous CoNS, S. haemolyticus was isolated from 4 sites $(n=5)$ - three hospitals, including the isolation ward of an ICU. This species is very frequently isolated nosocomial infections agent, causing various infections, including endocarditis or septicaemia, as well as it is recognized as one of the most multidrug resistant CoNS (34).

\section{CONCLUSIONS}

Based on the presented results it can be stated that microbiological aerosol within healthcare facilities changes with seasons of the year and its concentration may affect the health of both patients and personnel. Most densely populated premises proved to be characterized by the highest concentration of microbial aerosol. All of the detected species of Staphylococcus are coagulasenegative and are not typically associated with human infections, however, they are very common causal agents of nosocomial infections and infections in immunocompromised people. Such infections are dangerous to both patients and medical personnel and regular examinations of airborne microbiological contamination should be one of the methods employed in prevention against such infections. Moreover, ensuring proper maintenance of ventilation and air conditioning systems is one of the most important factors affecting the air quality.

\section{Acknowledgements}

The authors would like to thank MSc Eng. Katarzyna Juraszek, MSc Eng. Magdalena Musiorska, MSc Eng. Agnieszka Pawłowska and MSc Eng. Justyna Prajsnar for their support and help in the collection of samples.

\section{Funding}

This study was funded by the statutory measures of the University of Agriculture in Krakow, under the grant No. DS 3102/KM.

\section{Conflict of Interests}

None declared 


\section{REFERENCES}

1. Steinka I. The role of abiogenic factors in the transmission of microflora in hospital settings. Ann Acad Med Gedan. 2013;43:165-74.

2. Karwowska E, Miaśkiewicz-Pęska E, Andrzejewska-Morzuch D. Microbiological air contamination in premises of the primary health-care. Arch Environ Prot. 2013;39(4):51-8.

3. Bischoff WE, Wallis ML, Tucker BK, Reboussin BA, Pfaller MA, Hayden FG, et al. "Gesundheit!" Sneezing, common colds, allergies and Staphylococcus aureus dispersion. J Infect Dis. 2006;194(8):1119-26.

4. Fletcher LA, Noakes CJ, Beggs CB, Sleigh PA. The importance of bioaerosols in hospital infections and the potential for control using germicidal ultraviolet irradiation. Proceedings of the 1st Seminar on Applied Aerobiology; 2004 May 20; Murcia, Spain. Centro de Edafología y Biología Aplicada del Segura; 2004.

5. Tang TW, Li Y, Eames I, Chan PKS, Ridgway GL. Factors involved in the aerosol transmission of infection and control of ventilation in healthcare premises. J Hosp Infect. 2006;64(2):100-14.

6. Scott E, Bloomfield SF. The survival and transfer of microbial contamination via cloths, hands and utensils. J Appl Bacteriol. 1990;68(3):271-8.

7. Fernstrom A, Goldblatt M. Aerobiology and Its Role in the Transmission of Infectious Diseases. J Pathog. 2013;2013:493960. doi: 10.1155/2013/493960.

8. Kowalski WJ. Air-treatment systems for controlling hospital-acquired infections. HPAC Engineering. 2007;79(1):28-48.

9. Szewczyk EM, editor. Bacteriological diagnostics. Warsaw: Polish Scientific Publisher PWN; 2013. (In Polish.)

10. PN-Z-04008-08:1989. Air purity protection - Sampling - Sampling of ambient air (immission) for microbiological tests by aspiration and sedimentation method. Warsaw: PKN; 1989. (In Polish.)

11. Operator's Manual MAS-100TM professional Microbial Air Monitoring System for the Microbiological Testing of Air. Brussels, Belgium.

12. Górny RL. Biological aerosols - a role of hygienic standards in the protection of environment and health. Med Środ. 2010;13(1):41-51.

13. Edmiston CE, Seabrook GR, Cambria RA, Brown KR, Lewis BD, Sommers JR, et al. Molecular epidemiology of microbial contamination in the operating room environment: is there a risk for infection? Surgery. 2005;138(4):573-82.

14. Filipiak M, Piotraszewska- Pająk A, Stryjakowska-Sekulska M, Stach A, Silny W. Outdoor and indoor air microflora of academic buildings in Poznań. Postep Derm Alergol. 2004;21(3):121-7.

15. Gołofit-Szymczak M, Skowroń J. Microbiological contaminants in office buildings. Bezpieczeństwo Pracy. 2005;3:29-31. (In Polish.)

16. Kalwasińska A, Burkowska A, Wilk I. Microbial air contamination in indoor environment of a university library. Ann Agric Environ Med. 2012;19(1):25-9.

17. Scaltriti S, Cencetti S, Rovesti S, Marchesi I, Bargellini A, Borella P. Risk factors for particulate and microbial contamination of air in operating theatres. J Hosp Infect. 2007;66(4):320-6.

18. Kozioł-Montewka M. Respiratory tracts as a gateway of infections - hostpathogen interactions. Nowa Medycyna. 2009;1:3-7. (In Polish.)

19. Perlroth J, Choi B, Spellberg B. Nosocomial fungal infections: epidemiology, diagnosis and treatment. Med Mycol. 2007;45(4):321-46.
20. Kruczkowski P, Kolendarski W, Sikorski J. Design guidelines for general hospitals. Sanitary Installations. Book 5: Ventilation and air conditioning. Warsaw: Office of Health Services Studies and Projects; 1984. (In Polish.)

21. Li CS, Hou PA. Bioaerosol characteristics in hospital clean rooms. Sci Total Environ. 2003;305(1-3):169-76.

22. Pastuszka JS, Marchwińska-Wyrwał E, Wlazło A. Bacterial aerosol in Silesian hospitals: preliminary results. Pol J Environ Stud. 2005;14(6):88390.

23. Klánová K, Hollerová J. Hospital indoor environment: screening for microoganisms and particulate matter. Indoor Built Environ. 2003;12:61-7.

24. Palazzo ICV, d'Azevedo PA, Secchi C, Pignatari ACC. Staphylococcus hominis subsp. novobiosepticus strains causing nosocomial bloodstream infection in Brazil. J Antimicrob Chemother. 2008;62(6):1222-6.

25. Augustowska M, Dutkiewicz J. Variability of airborne microflora in a hospital ward within a period of one year. Ann Agric Environ Med. 2006;13(1):99-106.

26. Krzysztofik B. Air microbiology. Warsaw: Wydawnictwa Politechniki Warszawskiej; 1992. (In Polish.)

27. Reponen TA, Gazenko SV, Grinshpun SA, Willeke K, Cole EC. Characteristics of airborne actinomycete spores. Appl Environ Microbiol. 1998;64(10):3807-12.

28. Hirvonen MR, Nevalainen A, Makkonen M, Mönkkönen J, Savolainen K. Streptomyces spores from mouldy houses induce nitric oxide, TNFx and IL-6 secretion from RAW264.7 macrophage cell line without causing subsequent cell death. Environ Toxicol Phar. 1997;3(1):57-63.

29. Widerström M, Wiström J, Sjöstedt A, Monsen T. Coagulase-negative staphylococci: update on the molecular epidemiology and clinical presentation, with a focus on Staphylococcus epidermidis and Staphylococcus saprophyticus. Eur J Clin Microbiol Infect Dis. 2012;31(1):7-20.

30. Henry D, Ellison W, Sullivan J, Mansfield DL, Magner DJ, Dorr MB, et al. Treatment of community-acquired acute uncomplicated urinary tract infection with sparfloxacin versus ofloxacin. Antimicrob Agents Chemother. 1998;42(9):2262-6.

31. Ferreira AM, Bonesso MF, Mondelli AL, da Cunha ML. Identification of Staphylococcus saprophyticus isolated from patients with urinary tract infection using a simple set of biochemical tests correlating with 16S-23S interspace region molecular weight patterns. J Microbiol Meth. 2012;91(3):406-11.

32. Martínez-Lage JF, Martínez-Lage AL, Almagro MJ. Staphylococcus warneri ventriculoperitoneal shunt infection: failure of diagnosis by ventricular CSF sampling. Childs Nerv Syst. 2010;26(12):1795-8.

33. Ivić I, Karanović J, Pavičić-Ivelja M. Sepsis with multiple abscesses caused by Staphylococcus warneri: a case report. Cent Eur J Med. 2013;8(1):45-7.

34. Daniel B, Saleem M, Naseer G, Fida A. Significance of Staphylococcus haemolyticus in hospital acquired infections. J Pioneer Med Sci. 2014;4(3):119-25.

Received January 18, 2019

Accepted in revised form July 5, 2019 